\title{
Effect of Using Different Levels of Dried Taro (Colocasia esculanta) Waste without or with Dried Yeast (Saccharomyces cerevisiae) on Growth Performance of Growing Lambs. \\ Phillip, Y. L. ; A. A. Khir ; Amany A. Khayyal ; A. A. S. Mahgoub and O. Abdel-Salam Animal Production Research Institute, Agricultural Research Center, Ministry of Agriculture, Dokki, Giza, Egypt.
}

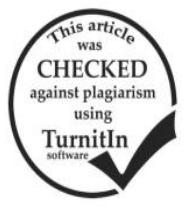

\section{ABSTRACT}

This study was conducted to investigate the effect of inclusion dried taro waste (DTW) without or with dried yeast (DY) in sheep rations on digestibility, rumen fermentation activity, blood parameters and growth performance of Ossimi lambs. Comparative feeding trial was applied with twenty four growing male lambs, averaging $21.5 \pm 2 \mathrm{~kg}$ of body weight where they were randomly divided into four similar groups $(6$ each) for feeding period of 150 days. The experimental rations were formulated as followed: $65 \%$ CFM+17.5\% rice straw (RS) $+17.5 \%$ DTW (R1); $65 \%$ CFM $+17.5 \%$ RS+17.5\% DTW with dried yeast (R2); 65\% CFM+35\% DTW (R3) and 65\% CFM+35\% DTW with dried yeast (R4). Dried yeast (Saccharomyces cerevisiae) was added at the rate of $5 \mathrm{~g} / \mathrm{h} / \mathrm{d}$. Digestibility trials were conducted with Ossimi rams to evaluate the digestibility and feeding values of the experimental rations. Results indicated that most nutrient digestibilities were markedly improved with the higher level of DTW in rations, where R3 and R4 had the highest $(\mathrm{P}<0.05)$ digestibility values for most nutrients versus those of the lower DTW ration, without or with DY (R1\& R1). Feeding values expressed as TDN did not significantly differ among the experimental rations, while DCP values were significantly improved with increasing the level of DTW, without or with DY. Addition of DY to R2 and R4 rations had no significant effect on feeding values expressed as TDN and DCP. Results of rumen liquor $\mathrm{pH}$ values were almost insignificant increased with increasing the proportion of DTW in rations without or with DY. Also, there were no significant differences in $\mathrm{NH}_{3}-\mathrm{N}$ and TVFA's concentrations among the experimental groups, with the best values being occurred with the low level of DTW-ration with DY additive (R2). No significant differences were observed among experimental groups concerning the all blood parameters except for albumin that was significant higher for animals fed ration contained only DTW with yeast (R4), while the differences respecting this item did not significant among the other treatments. Average daily gain was significantly higher with tested ration R2 than that of R3 or R4, but insignificant higher than that of R1ration. Daily DM intake was nearly comparable among groups. The best values of feed conversion and economic efficiency were observed with lambs fed ration that contained DTW + RS + DY (R2) while; these items did not improve with increasing DTW level. It could be concluded that DTW is a nutritious fodder ingredient for ration formulation for small ruminant. Therefore the low level of DTW (17.5\%) especially with yeast is highly recommended in practical feeding of growing lambs.

Keywords: Dried taro waste, dried yeast, sheep, digestibility, ruminal parameters, growth performance, blood parameters

\section{INTRODUCTION}

Livestock plays a very important role as an integral part of farming and rural life in developing countries; providing food and income for many farmers. The shortage of feeds to meet the nutritional requirements of the existing animal population is one of the most critical problems of animal production in Egypt. Minimizing the feed cost could be achieved through the use of untraditional cheaper feed ingredients or by using some feed additives to improve utilization of common feeds. Most vegetable residues are beneficially used as organic fertilizers or burned and severely causing an environmental pollution, but some are dried and stored as forage sources for ruminants or they may be grazing by livestock in the field (Renard, 2001). These residues, which producing by huge amounts are considerably a potential supply of manipulated feeds for feeding animals in Egypt and the most developing countries. Vegetables vines are the cheapest sources of essential amino acids, vitamins and minerals and nutritionally considerably working as a good source of energy and protein for ruminal microbes, including both soluble carbohydrates and readily digestible NDF fractions. The challenge for the feed formulation is to obtain least cost rations that fully match animal requirements (Maertens et al., 2002). Taro (Colocasia esculenta) has high yielding of succulent vegetative wastes and most its varieties contain irritating or acrid agents and therefore cannot be eaten in fresh state. It has been available in large quantities in terms of total area of about 6545 fedden with total production 102563 tons, according to the statistics of Ministry of Agriculture (2016) and the proportion of vegetative growth of about $35 \%$ and the proposed ratio of exploited vegetative growth of $17.5 \%$ (Desuki and El-Noubi, 1990). Taro by-product can be potentially using as a protein source for animals, especially pigs due to its leaves having (DM basis): $25 \% \mathrm{CP}$, $12.1 \% \mathrm{CF}, 10.7 \% \mathrm{EE}, 1.74 \% \mathrm{Ca}$, and $0.58 \% \mathrm{P}$ (FAO, 1993 ), in addition this by-product is rich in vitamins and minerals like thiamin, riboflavin, iron, phosphorus, zinc, vitamin $\mathrm{B} 6$, vitamin $\mathrm{C}$, niacin, potassium, copper and manganese (Wikipedia, the free encyclopedia http://en.wikipedia.org/ wiki/Taro). Taro has great potential as animal feed in the tropical and subtropical area where it is often a staple supply of feed for pigs (Wang, 1983). The anti-nutritional factors found in taro cocoyam include saponins, phytates, tannins and oxalates (Agwunobi et al., 2002 and Smith, 1982). These chemical compounds can be reduced by boiling, ensiling, and sun dried (Chhay et al., 2007). Many studies have indicated that yeast products can be using as feed supplements may have a significant positive effect on the performance of animals (Bakory, 2014). Yeast has an ability to scavenge oxygen from the rumen making ecosystem more favorable for growth and activity of the rumen anaerobic microbes. It also has the ability to increase cellulolytic bacteria activity in the rumen and increases nutrient digestibility, especially for rich fiber diets. Yeasts have also been shown to regulate the rumen $\mathrm{pH}$ and limit acidosis risks through regulating both of lactate producing, lactate utilizing bacteria and it is a rich source of nutrients like peptides, vitamins, organic acids and cofactors which may be required by the rumen bacteria (Montes de Oca et $a l ., 2016)$. The effect of yeast on animal performance and health status varies depending on the livestock conditions, dose, age, and even between studies. However, mode of 
action of yeast remains unknown (Belhassen et al., 2016). Dried yeast (Saccharomyces cerevisiae) addition inhibit pathogenic bacteria, change microbial metabolism and decrease intestinal pH (Makled, 1991; Miles and Bootwella, 1991), and improved nutritional value of poor quality forages, as well as improved feed intake and milk yield in dairy cows (Jouany and Morgavi, 2007).

The main target of this study was to investigate the effect of dried taro waste (DTW) levels as nonconventional and cheaper feedstuff without or with dried yeast on digestibility, growth performance and some blood parameters of lambs.

\section{MATERIALS AND METHODS}

The present study was carried out during the period from October 2015 up to February 2016 at Seds experimental Station, belonging to Animal Production Research Institute (APRI), Agriculture Research Center, Ministry of Agriculture, Dokki, Giza, Egypt. Taro waste that mainly consisted of leaves and petioles (false stems) was collected from Beni-Sueif Governorate directly after harvest their fruits and chopped to $2-3 \mathrm{~cm}$ pieces then sunair dried for being use in this experiment, while dried yeast (DY) was provided by Egyptian Sugar and Integrated Industrial Company, Hawamdia, Giza, Egypt.

\section{Experimental animals and feeding:}

A comparative feeding trial was conducted with using twenty four male Ossimi lambs with an average live body weight $\sim 21.5 \mathrm{~kg}$, and 6 months of age using randomized complete block design and lasted 150-d experimental period. Lambs were randomly divided into four similar groups (6 lambs for each). Each group was assigned randomly to feeding one of experimental rations where R1 received $65 \%$ concentrate feed mixture $(\mathrm{CFM})+17.5 \%$ rice straw (RS)+17.5\% DTW, R2: $65 \%$ CFM+17.5\% RS+17.5\% DTW with yeast $(5 \mathrm{~g} / \mathrm{h} / \mathrm{d})$, R3: 65\% CFM $+35 \%$ DTW, and R4: 65\% CFM $+35 \%$ DTW with yeast $(5 \mathrm{~g} / \mathrm{h} / \mathrm{d})$. The amount of CFM were offered twice daily at 8.00 a.m. and 4.00 p.m. in two equal portions and roughage was offered at the beginning of feeding. Animals were housed in four shaded yards and they were weighed biweekly. Daily amounts of experimental rations were calculated according to NRC (1985). Drinking water was available at all times. The experimental animals were healthy and free from external and internal parasites and kept in pens under similar condition. Samples of the ration ingredients were analyzed for crude protein $(\mathrm{CP})$, crude fiber (CF), ether extract (EE) and ash. The chemical analysis of CFM, DTW, RS, DY and the calculated composition of the experimental rations are shown in Table (1).

Digestibility trials:

Digestibility trials were carried out at the end of feeding trial to determine the nutrient digestibility and the feeding values of the experimental rations using twelve Ossimi rams (3for each treatment). Animals were placed in individual metabolic cages for 21 days (14 days as a preliminary period, followed by 7 days as collection period). Animals in each group were fed on one of experimental rations which offered twice daily at 8.00 a.m. and 4.00 p.m., while water was offered freely along the day. Sub samples $(10 \%)$ of feces was taken once daily then stored at $-18^{\circ} \mathrm{C}$. At the end of the collection period composite fecal samples for each ram were dried at $60^{\circ} \mathrm{C}$ for $72 \mathrm{hrs}$.

\section{Chemical analysis:}

Feed and fecal samples were ground through $1 \mathrm{~mm}$ screen on a Wiley mill grinder and representative samples of feed and feces were analyzed for dry matter (DM), crude protein $(\mathrm{CP})$, crude fiber $(\mathrm{CF})$, ether extract $(\mathrm{EE})$ and ash according to A.O.A.C (2007). At the end of collection period of the digestibility trial, rumen liquor (RL) samples and blood samples were taken from each animal at $4 \mathrm{hrs}$. after the morning meal. Rumen liquor samples were collected by stomach tube. The ruminal $\mathrm{pH}$ values were measured immediately using Orian 680 digital pH meter. Samples were strained through four layers of cheese cloth, and then ammonia nitrogen $(\mathrm{NH} 3-\mathrm{N})$ was determined according to Conway, and O'Malley (1957). Total volatile fatty acids (TVFA's) concentration was estimated by using steam distillation methods (Warner, 1964). Mineral extracts of dried taro waste (DTW) was prepared and analyzed for $\mathrm{Ca}$ after a wet digestion with a mixture of nitric, sulphuric and perchloric acids using an atomic absorption (Unicam 919). Phosphorus was determined colorimetrically, using molybdovanadate reagent according to A.O.A.C. (2007). Total oxalate was determined using the method of Ukpabi and Ejidoh (1989).

Blood samples were withdrawn from jugular vein in heparinized tubes and centrifuged for $20 \mathrm{~min}$. at 3000 r.p.m. Plasma was frozen and stored at $-18^{\circ} \mathrm{C}$ until the time of analysis. Various chemical parameters were colorimetrically determined using commercial kits; following the same steps as described by manufactures. Total protein (TP) was measured as described by the Biuret method according to Henry and Todd (1974); albumin (A) was assayed according to Doumas et al. (1971); globulin was calculated by subtracting the albumin value from total protein value; liver functions were assessed by measuring the activities of aspartate aminotransferase (AST) and alanine aminotransferase (ALT) according to Reitman and Frankel (1957); cholesterol was estimated according to Stein (1986); uric acid was detected according to Barham and Trinder (1972); creatinine was measured according to Faulkner and King (1976), while calcium was measured according to Gindler and King (1972).

\section{Statistical analyses:}

All data were analyzed using the general linear models procedure of SAS (2004) where data of percentages were subjected to arc-sin transformation to approximate normal distribution before being analyzed and means were separated using Duncan's multiple range tests (Duncan, $1955)$ for the comparison among group means of the experimental rations when the main effects were significant. The model used was: $\quad \mathbf{Y}_{\mathrm{ij}}=\boldsymbol{\mu}+\mathbf{T}_{\mathbf{i}}+\mathbf{e}_{\mathbf{i j}}$

Where: $Y_{i j}=$ the observation of $i j, \mu=$ overall mean of $\mathrm{Y}_{\mathrm{ij}}, \mathrm{T}_{\mathrm{i}}=$ Effect of $\mathrm{i}$ (treatments), $\mathrm{e}_{\mathrm{ij}}=$ the experimental random error.

\section{RESULTS AND DISCUSSION}

\section{Chemical composition:}

Chemical analysis of CFM, DTW, RS, DY and calculated composition of experimental rations are shown in Table (1). The chemical composition of CFM was closely 
comparable to those using commonly in practical field of ruminant feeding. Also, the nutrient content values of rice straw is within the normal range that widely recorded in the literature. The chemical composition of DTW was contained $13.52,23.64,2.27,34.81$ and $25.76 \%$ for $\mathrm{CP}, \mathrm{CF}, \mathrm{EE}, \mathrm{NFE}$ and ash, respectively. The present values are within the range that reported by Chhay et al. (2009), Du Thanh Hang and Preston (2010), Ngo Huu Toan and Preston (2010) and Du Thanh Hang et al. (2014). Concentrations of calcium, phosphorus and total oxalate of DTW were $2.20,0.31 \%$ and $7.9 \mathrm{mg}$ g-1, respectively. Leterme et al. (2005) showed that leaves of taro cocoyam (Xanthosoma sagittifolium) contained calcium (up to $69 \mathrm{~g} \mathrm{~kg}-1 \mathrm{DM}$ ). Dahlgren and Savage (2007) showed that younger taro leaves contained $5.89 \mathrm{~g}$ total oxalate per $\mathrm{kg}$ fresh weight compared to $4.43 \mathrm{~g}$ total oxalate per $\mathrm{kg}$ fresh weight for mature leaves grown. Generally, DTW and DY are rich in most nutrients and some bio-compounds and could be used as an ingredient or as an excellent feed supplement in sheep rations. Experimental rations appeared clear differences in its chemical composition as a result of increasing level of DTW in ration from $17.5 \%$ to $35 \%$ in tested rations.

Table 1. Chemical analysis of ration ingredients and calculated composition of experimental rations (on DM basis, \%).

\begin{tabular}{|c|c|c|c|c|c|c|c|c|c|}
\hline Item & DM & OM & CP & $\mathbf{C F}$ & $\mathbf{E E}$ & NFE & Ash & $\mathbf{C a}$ & $\mathbf{P}$ \\
\hline CFM & 92.34 & 82.62 & 15.08 & 17.31 & 2.28 & 47.95 & 17.38 & & \\
\hline Dried taro waste (DTW) & 90.67 & 74.24 & 13.52 & 23.64 & 2.27 & 34.81 & 25.76 & 2.20 & 0.31 \\
\hline Rice straw (RS) & 92.43 & 83.17 & 4.38 & 34.84 & 0.838 & 43.11 & 16.83 & - & - \\
\hline Dried yeast (DY) & 91.20 & 94.10 & 45.58 & 0.426 & 0.436 & 47.66 & 5.90 & 0.13 & 1.51 \\
\hline Experimental rations: & & & & & & & & & \\
\hline $\begin{array}{l}\mathrm{R} 1 \\
\mathrm{R} 2\end{array}$ & $\begin{array}{l}92.07 \\
92.07\end{array}$ & $\begin{array}{l}81.27 \\
81.27\end{array}$ & $\begin{array}{l}12.93 \\
12.93\end{array}$ & $\begin{array}{l}21.48 \\
21.48\end{array}$ & $\begin{array}{l}2.03 \\
2.03\end{array}$ & $\begin{array}{l}44.84 \\
44.84\end{array}$ & $\begin{array}{l}18.73 \\
18.73\end{array}$ & & \\
\hline R3 & 9175 & 79.64 & 14.52 & 1956 & 228 & 4328 & 2036 & & \\
\hline R4 & 91.76 & 79.72 & 14.54 & 19.50 & 2.28 & 43.41 & 20.28 & & \\
\hline
\end{tabular}

Ingredients (CFM): 42.0 yellow corn, 13.0 soybean meal, 38.5 wheat bran, 3.0 molasses, 0.5 mineral premix, 2.0 calcium carbonate and $1.0 \%$ salt (as fed).

* Dried taro waste contained $7.9 \mathrm{mg} \mathrm{g}^{-1}$ total oxalate.

R1: CFM+RS+DTW, R2: CFM+RS+ DTW+ DY, R3: CFM+ DTW and R4: CFM+ DTW+ DY.

Nutrients digestibility and feeding values:

Digestion coefficients and feeding values of experimental rations are given in Table (2). Results of digestibility revealed that the digestibility of most nutrients were significantly improved with increasing level of the DWT in rations and the highest $(\mathrm{P}<0.05)$ values were observed with animals fed rations contained DTW as a sole roughage either without yeast (R3) or with yeast (R4). The positive effect of DTW without or with yeast on nutrients digestibility could be regarded to its high content of protein or essential amino acids needed to enhance rumen microbial activity. Feeding values as TDN for all rations either without or with yeast addition did not affected by increasing level of DWT, however DCP values were significantly $(\mathrm{P}<0.05)$ improved as increasing the level of DWT in ration. Results in table (2) revealed that addition of yeast to ration had no significant effect on either nutrient digestibility or feeding values as TDN or DCP however, digestibility of $\mathrm{CP}$ and $\mathrm{CF}$ were insignificant improved with yeast addition. Recently the findings of Khayyal et al. (2017) revealed that nutrient digestibilities did not affected by rabbits fed rations contained different levels $(7.5,15$ and $22.5 \%$ ) of dried taro without or with dried yeast waste $(0.5 \%)$ being those fed ration contained $22.5 \%$ dried taro waste without dried yeast mostly had the lowest values in digestibility of DM, OM, CF, NFE and TDN. In other study respecting DTW, Chhay et al. (2007) found that digestibility of DM, OM, CF were higher for pigs fed dried taro leaves than those fed taro silage. Furthermore, Manivanh and Preston (2011) found that apparent digestibility of DM, OM, CP tend to increase with increasing the proportion of taro silage in pigs ration from $25 \%$ to $100 \%$ ( being $85 \%$ to $89 \%$ for DM and OM, and from $81 \%$ to $88 \%$ for $\mathrm{CP}$ ). Regarding yeast addition, Andrighetto et al. (1993) reported that DM, CP, NDF and ADF digestibility did not affected by addition of yeast (20$40 \mathrm{~g} / \mathrm{d}$ ) to sheep ration. On the other hand, El-Nahas et al. (2009), Mousa et al. (2012) and Kassab and Mohamed
(2013) reported that nutrient digestibilities were increased by sheep fed rations contained yeast $(4 \mathrm{~g}-8 \mathrm{~g} / \mathrm{h} / \mathrm{d})$. Similarly, addition of yeast to the diet of sheep could be improving the digestibility of protein and hemicellulose (Allam et al., 2001). This improvement of nutrient digestibilities could be attributed to the enhancement of microbial efficiency via stimulating rumen proteolytic bacteria and increasing the number of cellulytic bacteria (Williams, 1988 and Dawson et al., 1990). In further explanation, Ojokoh (2007) reported that micro-organism (yeast) can be playing an important role that had either positive or negative effect. The positive effect of microorganism is generally regarded as part of the fermentation; product preservation, decrease anti-nutritional factors and increase the availability of nutrients, vitamins, essential amino acids (proteins) by improving digestibility of protein and fiber.

Table 2. Effect of feeding the experimental rations on digestibility and feeding values.

\begin{tabular}{|c|c|c|c|c|c|}
\hline \multirow[b]{2}{*}{ Item } & \multicolumn{4}{|c|}{ Experimental rations } & \multirow[b]{2}{*}{$\pm \mathbf{S . E}$} \\
\hline & R1 & R2 & R3 & R4 & \\
\hline \multicolumn{6}{|c|}{ Digestibility, \% } \\
\hline $\mathrm{DM}$ & $65.81^{\mathrm{b}}$ & $66.77^{\mathrm{b}}$ & $69.68^{\mathrm{a}}$ & $70.35^{\mathrm{a}}$ & \pm 0.570 \\
\hline OM & $68.70^{\mathrm{c}}$ & $69.21^{\mathrm{bc}}$ & $70.60^{\mathrm{ab}}$ & $71.98^{\mathrm{a}}$ & \pm 0.502 \\
\hline $\mathrm{CP}$ & 66.33 & 68.41 & 67.52 & 69.27 & \pm 2.596 \\
\hline $\mathrm{CF}$ & 63.94 & 65.83 & 64.14 & 66.41 & \pm 1.809 \\
\hline $\mathrm{EE}$ & $75.65^{\mathrm{ab}}$ & $70.71^{\mathrm{b}}$ & $80.62^{\mathrm{a}}$ & $79.44^{\mathrm{a}}$ & \pm 2.588 \\
\hline NFE & $71.77^{\mathrm{b}}$ & $71.31^{\mathrm{b}}$ & $74.52^{\mathrm{a}}$ & $74.85^{\mathrm{a}}$ & \pm 1.610 \\
\hline \multicolumn{6}{|c|}{ Feeding values, \% } \\
\hline TDN & 56.91 & 57.20 & 57.10 & 57.85 & \pm 0.394 \\
\hline DCP & $7.55^{\mathrm{b}}$ & $7.78^{\mathrm{b}}$ & $9.55^{\mathrm{a}}$ & $9.80^{\mathrm{a}}$ & \pm 0.360 \\
\hline
\end{tabular}

\section{Rumen parameters:}

The ruminal $\mathrm{pH}$ values, concentration of $\mathrm{NH} 3-\mathrm{N}$ and TVFA's are shown in Table (3). Data revealed that $\mathrm{pH}$ values were insignificantly increased with increasing level of DTW in rations especially with yeast addition (R4). Increasing in $\mathrm{pH}$ was generally due to the production of 
ammonia (Odetokun, 2000) that largely depending on protein-based fermentation (Adenik et al., 2007). There were no significant differences observed in concentrations of ruminal NH3-N or TVFA's among the different experimental rations. The slightly increases in concentration of ruminal NH3-N with increasing DTW level may be due to high protein content of DTW. The production of ammonia and amines is quite common during fermentation as a result of protein hydrolysis. On the other hand, addition of yeast to ration led to insignificant decrease of NH3-N and insignificantly increases of TVFA's for R4 only. Hassan (2014) reported that $\mathrm{pH}$ values and TVFA's concentration were increased and $\mathrm{NH} 3-\mathrm{N}$ significantly decreased by calves fed yeast ration compared with others fed control ration $(0$ yeas). However, Khorshed (2000) found that a significant increase in ruminal NH3-N concentration with yeast culture addition into crop residue-ration of ruminants. This increase of TVFA's concentration may be due to the increase of digestibility of organic matter (El-Ashry et al., 2003), higher digestibility of $\mathrm{CF}$ or may be resulted from altered microbial population and microbial activity (Doane et al., 1997). Allam et al. (1984) reported that the ruminal TVFA's concentration could be affected by DM digestibility, rate of absorption, rumen $\mathrm{pH}$ and microbial population in the rumen and their activity.

Table 3. Effect of feeding the experimental rations on ruminal parameters.

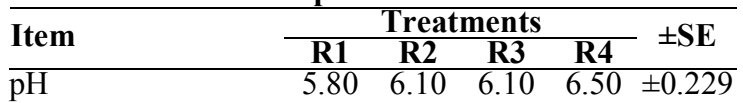

NH3-N, mg/100 ml RL $10.03 \quad 8.73 \quad 10.97 \quad 9.52 \quad \pm 1.554$

TVFA's, meq/ $100 \mathrm{ml}$ RL $18.00 \quad 18.33 \quad 15.65 \quad 17.67 \pm 1.698$

${ }^{a}$ and ${ }^{b}$ means in the same row with different superscripts are significantly $(P \leq 0.05)$ different.

$\mathrm{SE}=$ Standard error

Blood parameters:

The results of blood parameters for rams fed the experimental rations are presented in Table (4). Data revealed that neither level of DTW nor the addition of yeast had any significant differences among treatments concerning the concentrations of all blood parameters (total protein, globulin, AST, ALT, cholesterol, uric acid, creatinine and Ca) except for albumin. The concentration of total protein was insignificant increased with increasing level of DTW in ration. Addition of yeast to ration led to insignificant increase of plasma total protein while, plasma albumin concentration was significantly increased as a result of yeast addition to ration contained DTW as a sole roughage (R4) only. These increases in plasma total protein and albumin concentrations may be due to high protein content of DTW. Plasma total protein and albumin concentrations have been reported to be in direct response to protein quality and protein intake (Eggum, 1989 and Onifade and Abu, 1998). Onifade et al. (1999), Mousa et al. (2012) and Kassab and mohamed (2013) reported that blood protein and albumin levels increased and levels of cholesterol, ALT and AST decreased with supplement yeast in rations of rabbits and sheep. Mani et al. (1989) reported that non-significant reduction in liver cholesterol, while liver triglycerides were increased for hypercholesterolemia rats fed 10 or $20 \%$ dried taro leaves with or without cholesterol. The insignificant decrease of plasma cholesterol could be linked to contents of taro saponins, whose are known to bind with bile acids and cholesterol and therefore such compounds can be purging these fatty compounds from the body and lowering the cholesterol level (Olajide, 2012).

Table 4. Effect of feeding the experimental rations on blood parameters.

\begin{tabular}{|c|c|c|c|c|c|}
\hline \multirow{2}{*}{ Item } & \multicolumn{4}{|c|}{ Treatments } & \multirow[b]{2}{*}{$\pm \mathrm{SE}$} \\
\hline & R1 & R2 & R3 & R4 & \\
\hline Total protein, $\mathrm{g} / \mathrm{dl}$ & 6.31 & 6.44 & 6.49 & 6.83 & \pm 0.171 \\
\hline Albumin, $\mathrm{g} / \mathrm{dl}$ & $3.90^{\mathrm{b}}$ & $3.91^{\mathrm{b}}$ & $3.87^{b}$ & $4.38^{\mathrm{a}}$ & \pm 0.140 \\
\hline Globulin, $\mathrm{g} / \mathrm{dl}$ & 2.41 & 2.53 & 2.62 & 2.45 & \pm 0.104 \\
\hline $\mathrm{AST}, \mathrm{U} / \mathrm{L}$ & 62.60 & 61.5 & 60.14 & 67.23 & \pm 6.655 \\
\hline ALT, U/L & 40.09 & 39.45 & 39.57 & 43.16 & \pm 4.790 \\
\hline Cholesterol, g/dl & 111.19 & 109.76 & 109.52 & 100.47 & \pm 5.213 \\
\hline Uric acid, g/dl & 4.89 & 4.96 & 5.02 & 5.11 & \pm 0.308 \\
\hline Creatinine, $\mathrm{mg} / 100 \mathrm{ml}$ & 1.55 & 1.50 & 1.51 & 1.56 & \pm 0.084 \\
\hline $\mathrm{Ca}, \mathrm{g} / \mathrm{dl}$ & 8.27 & 8.28 & 8.16 & 7.93 & \pm 0.371 \\
\hline
\end{tabular}

Also, El-Nahas et al. (2009) reported that yeast supplementation led to insignificant changes in concentration of total protein, albumin and globulin in plasma of lambs. Otherwise, Kowalik et al. (2012) reported that concentration of serum total protein decreased significantly by addition of live cell yeast to heifer's ration in comparison with those fed control ration. In regard of blood cholesterol, Ismail et al. (2004) with rabbits found that supplemented their diets with yeast culture significantly $(\mathrm{P} \leq$ 0.05 ) reduced the blood plasma cholesterol levels. Also, Kowalik et al. (2012) reported that serum total cholesterol concentration was decreased significantly by heifers fed ration contained live cell yeast compared to those fed control one. Generally, the obtained values of blood parameters in this study indicate that all experimental animals were performed with normal physiological and healthy status.

Growth performance and economic efficiency:

The measurements of daily gain, feed intake, feed conversion and economic efficiency are presented in Table (5). Daily DM intake was nearly comparable among groups, being it was slightly decreased with increasing the proportion of DTW in lamb's rations. These results are in agreement with those recorded by Manivanh and Preston (2011) who reported that DM intake and OM intake were decreased for pigs by increasing the proportion of taro silage from 25 to $100 \%$ and the highest values of

DMI and OMI were observed with 50\% taro silage. Average daily gain (ADG) was insignificant decreased with increasing DTW level in the experimental rations. Lake of effect due to the addition DY was found between either rations R1 \& R2 or R3 \& R4 ones, however the best daily gain value was associated with $R 2$. This significant increase in ADG might be due to the high TDN intake $\left(\mathrm{kg} \mathrm{d}^{-1}\right)$ for lambs in R2 (0.719). In relation with this point, Mikulec et al. (2010) reported that supplementation with yeast (0.5-1 $\mathrm{gd}^{-1}$ ) did not affect weight gain and body weight with low protein level in the diet of fattening lambs. Also, Piennar et al. (2012) found that the inclusion of yeast in diets had no effect on lamb growth performance and this may be due to low fiber content of diet. Concerning feed conversion measurements in the present study, its values did not significant affected by the dietary treatments, being the best value was occurred with R2-ration. These results are in disagreement with those obtained Chhay et al. (2014) who reported that feed conversion ratio was improved by increasing the proportion of taro foliage silage up to $60 \%$ in 
replacement of rice bran with gilts. In respect of economic efficiency, results in Table 5 revealed that feed cost $/ \mathrm{kg}$ gain was markedly lower (2.95 LE) with the lower level of DTW in ration $\mathrm{R} 2$, in comparison with the other dietary treatments. In turn the daily profit (L.E.) was markedly higher with the lower level DTW-ration (R2) which supplemented with DY, compared with the other ones. Economic (daily profit) efficiency were higher with $17.5 \%$ DTW-ration (R2) with yeast than that of the other treatments.

Table 5. Effect of experimental rations on growth performance and economic efficiency.

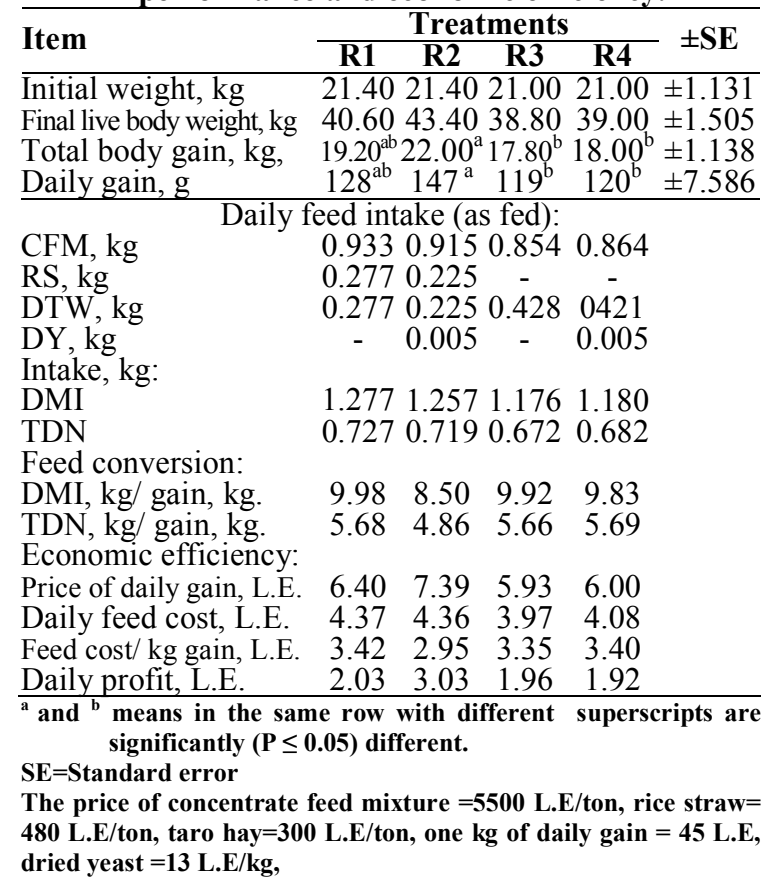

\section{CONCLUSION}

In conclusion, dried taro waste could be used as a beneficial ingredient in rations of growing lambs with positive effect on nutrient digestibility, some blood parameters, growth performance and economic efficiency, in particularly with the tested ration that contained the lower level of DTW with DY-additive.

\section{ACKNOWLEDGMENTS}

The authors express their gratitude to Dr. Safaa Nady for her kind help along the practical stage of the experiment in the farm.

\section{REFERENCES}

Adenike, A.O. A., O.O. Mopelola and A.D.V. Ayasina (2007). Microbial studies and biochemical characteristics of controlled fermented Afuyo - a Nigerian fermented food condiment from Prosops Africana (Gull and Perr.) Taud: Pakistan Journal of Nutrition, 6 (6): 620-627.

Agwunobi, L.N., P.O. Angwukan, O.O. Cora and M.A. Isika (2002). Studies of the use of Colocasia esculenta (Taro cocoyam) in the diets of weaned pigs. Tropical Animal Health and Production, 34 (3): 241-247.
Allam, S.M., A.K. Abou-Raya, E.A. Gehad and T.M. ElBedawy (1984). Nutritional studies by sheep and goats fed $\mathrm{NaOH}$ treated straw. Egyptian British Conf. on Animal and Poultry Production. Zagazig, 11-13 Sept., pp. 53.

Allam, A.M., K. El-Shazly, B.E.A. Borhami and M.A. Mohamed (2001). Effect of baker's yeast (Saccharomyces cerevisae) supplementation on digestion in sheep and milk response in dairy cows. Egyptian J. Nutrition and Feeds, 4 (special issue): 315.

Andriightto, I, L. Bailoni, G. Cozzi and P. Berzzaghi (1993). Effect of yeast culture addition digestion in sheep fed high concentrate diet. Small Ruminant Researh.12 (1): 27-34.

A.O.A.C. (2007). Official Method of Analysis (18th Ed.) Association of Official Analytical Chemists. Washington, D.C., U.S.A.

Bakory, M.T.A. (2014). Yeast culture in animal nutrition: A review. Bioscience Research, 11(1): 10-19.

Belhassen T., A. Bonai, Z.S. Gerencsér, Z.S. Matics, T. Tuboly, R. Bergaoui and M. Kovacs (2016). Effect of diet supplementation with live yeast (Saccharomyces cerevisiae) on growth performance, caecal ecosystem and health of growing rabbits, World Rabbit Sci., 24: 191-200.

Barham, D. and P. Trinder (1972). Analyst, 97: 142.

Chhay, Ty, K. Borin, T.R. Preston and S. Mea (2007). Intake, digestibility and $\mathrm{N}$ retention by growing pigs fed ensiled or dried taro (Colocasia esculenta) leaf as the protein supplement in basal diets of rice bran/broken rice or rice bran/cassava root meal. Livestock Research for Rural Development. Volume19, Article\#137, from http: //www.cipav.org. co/lrrd/19/9/ chha19137.htm

Chhay, Ty, K. Borin and T.R. Preston (2009). Effect of processing taro foliage on growth of pigs fed two grades of rice bran. Livestock Research for Rural Development, 21 (11), Article \#200. http://www. lrrd.org/lrrd21/11/chha21200.htm

Chhay, Ty, K. Borin and T.R. Preston (2014). Ensiled taro foliage replacing rice bran in diets of gilts during pregnancy and lactation. Livestock Research for Rural Development, 26 (6).

Conway, E.F. and E. O'Mally (1957). Micro diffusion methods. Ammonia and urea using buffered absorbents. Biochem. J., 36: 655.

Dahlgren, E.M. and G.P. Savage (2007). Reduction in oxalate content during the preparation of a traditional Tongan dessert. Journal of Food, Agriculture \& Environment, 5 (3\&4): 29.

Dawson, K.A., K.E. Newman and J.A. Boling (1990). Effects of microbial supplements containing yeast and lactobacilli on roughage-fed ruminal microbial activities. J. Anim. Sci., 63: 3392.

Desuki, A. and H.M. El-Noubi (1990). Feed resources development for animal production. Animal Production Research Institute, German Project (GTZ).

Doumas, B., W. Walson and H. Blgga (1971). Albumin standards and measurement of serum with bromocresol green. Clin.Chem. Acta, 31: 87. 
Doane, P.H.; P. Schofield and A.N. Pell (1997). Neutral detergent fiber disappearance and gas volatile fatty acid production during the in vitro fermentation of six forage. J. Anim. Sci., 75: 3342-3352.

Duncan, D.B. (1955). Multiple ranges and multiple F-Test. Biometrics, 1: 42.

Du Thanh Hang and T.R. Preston (2010). Effect of processing Taro leaves on oxalate concentrations and using the ensiled leaves as a protein source in pig diets in central Vietnam. Livest. Res. Rural Dev., 22 (4): 68.

Du Thanh Hang, Than Thi Thanh Tra, Nguyen Thi Loc, Phan Vu Hai, Nguyen Dang Qui, Ha Le Ngoc Linh and Le Duc Ngoan (2014). Taro (Colocasia esculenta (L) schott) and banana pseudo-stem as energy sources for pigs in Central Vietnam. Livestock Research for Rural Development, 26 (6), 2014.

Eggum, B.O. (1989). Biochemical and methodological principles. In: Bock, H.-D., Eggum, B.O., Low, A.G., Simon, O., Zebrowska, T. (Eds), Protein Metabolism in Farm Animals. Evaluation, Digestion, Absorption, and metabolism. Oxford Science Publications, Deutscher Landwirtscafts Verlag, Berlin, pp.1-52.

El-Ashry, M.A., A.M. Kholif, M. Fadel, H.A. El-Alamy, H.M. El-Sayed and S.M. Kholif (2003). Effect of biological treatments on chemical composition, invitro and in-vivo nutrients digestibilities of poor quality roughage. Egyptian J. Nutrition and Feeds, 5(1): 55-69.

El-Nahas, H.M., KH.M.M. Mousa, E.E. Ragheb and Safaa N. Abd El-Azeam (2009). Effect of some feed additives on digestibility coefficients, blood parameters, growth performance and feed efficiency of growing lambs. Egyptian J. Nutrition and Feeds, 12 (2): 257-267.

Faulkner, W.R. and J.W. King (1976). Fundamentals of Clinical Chemistry, 2nd ed. (NW Tietz, Ed.), Saunders, Philadelphia, pp. 994-998.

FAO (1993). FAOSTAT. Food and Agricultural Organization of the United Nations.

Gindler, E.M. and J.D. King (1972). Rapid colorimetric determination of calcium in biologic fluids with methylthymol blue. Am. J. Clin. Pathol., 58(4):376-82.

Hassan, E.H. (2014). Effect of fenugreek and dried baker's yeast as natural additives on growth performance, nutrient digestibility and rumen fermentation parameters of growing buffaloes calves. Egyptian J. Nutrition and Feeds, 17 (1): 1-8.

Henry, J.B. and S.D. Todd (1974). Clinical Diagnosis and Measurement by Laboratory Methods, $16^{\text {th }}$ Ed., W.B. Saunders and Co., Philadelphia., PA. P260.

Ismail, F.S.A., M.H. Rabie and A.E. Abd El-Khalek (2004). Effects of some sources of yeast cultures as feed additives on growth performance of New Zealand White rabbits. Egyptian J. of Rabbit Sci., 14 (2): 101116.

Jouany, J.P. and D.P. Morgavi (2007). Use of 'natural' products as alternatives to antibiotic feed additives in ruminant production. Animal, 1 (10): 1443-1466.
Kassab, A.Y. and A.A. Mohammed (2013). Effect of dietary live dried yeast on some physiological responses and reproductive perfomanc in Sohagi ewes. Egyptian J. Nutrition and Feeds, 16 (2): 213223.

Khayyal, Amany A., E.O.A. Bakr, Y.L. Phillip, A.M. Hussein and A.A.Khir (2017). Effect of diets containing dried taro (Colocasia esculanta) waste and dried yeast (Saccharomyces cerevisiae) on performance of growing rabbits. J. Anim. and Poultry Prod., Mansoura Univ., 8 (6):109-117.

Khorshed, M.M.A. (2000). Different treatments for improving nutritional quality of some crop residues used in ruminant nutrition. Ph. D. Fac. of Agric. Ain Shams Uni.

Kowalik, B., J. Skomiał, J.J. Pająk, M. Taciak, M. Majewska, G. Bełżecki (2012). Population of ciliates, rumen fermentation indicators and biochemical parameters of blood serum in heifers fed diets supplemented with yeast (Saccharomyces cerevisiae) preparation. Animal Science Papers and Reports, 30: 329-338.

Leterme, P., Angela M. Londoño, F. Estrada, W.B. Souffrant and A. Buldgen (2005). Chemical composition, nutritive value and voluntary intake of tropical tree foliage and cocoyam in pigs. J. Sci. Food Agric., 85:1725-1732.

Maertens, Y., A. Tegegne, A. Yami and N.N. Umunna (2002). Evaluation of non-conventional agroindustrial by-products as supplementary feeds for ruminants: in vitro and metabolism study with sheep. Small Ruminants Research, 44: 25-35.

Makled, M.N. (1991). The potentials of probiotics in poultry feed. A review $3^{\text {rd }}$ Scientific Symp. for Animal Poultry and Fish Nutrition, Sakha, Kafr-ELSheikh, Egypt, pp. 54-68.

Mani U.V., M. Sharma, K. Waghray, U. Lyer and I. Mani (1989). Effect of colocasia leaves (Colocasia antiquorum) on serum and tissue lipids in cholesterol-fed rats. Plant Foods Hum. Nutr., 39(3): 245-255.

Manivanh N. and T.R. Preston (2011). Taro (Colocacia esculenta) silage and rice bran as the basal diet for growing pigs; effects on intake, digestibility and $\mathrm{N}$ retention. Livestock Research for Rural Development, Volume 23, Article \#55. Retrieved January 27, 2012, from http://www.lrrd.org/ lrrd23 / 3/ noup23055.htm.

Mikulec, Z., T. Masek, B. Habrun and H.Valpolic (2010). Influence of live yeast cell (Saccharomyces cerevisiae) supplementation to the diet of fattening lambs on growth performance and rumen bacterial number. veterinarski arhiv. 80 (6):695-703.

Miles, R.D. and S.M. Bootwella (1991). Direct feed microbial in animal production. National Feed Ingredients Association, Desmonres, Iowa, USA.

Ministry of Agriculture (2016). Bulletin of the Agricultural Statistics, part (2) summer \& nili crops, 2014/2015, pp. 203. 
Montes de Oca, R., A.Z.M. Salem, A.E. Kholif, P. Fernandez, J.L. Zamora, H. Monroy, L.S. Pérez and J. Acosta (2016). Mode of action of yeast in animal nutrition. In book: Yeast Additive and Animal Production, Publisher: PubBioMed Central Research Publishing Services (India), Editors: A.Z.M. Salem, A.E. Kholif, A.K. Puniya, pp.14-20

Mousa, Fh. M., O.M. El-Malky, O.F. Komonna and S.E. rashwan (2012). Effect of live dried yeast supplementation on digestion coefficient, some rumen fermentation, blood constituents and some reproductive parameters in Rahmani sheep. Journal of American Science, 8 (20): 291-303.

Ngo, H.T. and T.R. Preston (2010). Taro as a local feed resource for pigs in small scale household condition. Livest. Res. Rural Dev., 22 (8).

N.R.C. (1985). Nutrient Requirements of Sheep. Academy of Sciences. National Research Council, Washington, D.C.

Odetokun, S.M. (2000). Effect of fermentation on some physio-chemical properties, antinutrients and in-vitro multi-enzymes digestibility of selected legumes. $\mathrm{Ph} . D$. Thesis Federal Unversity of Technology, Akure, Nigeria, pp. 148.

Ojokoh, A.O. (2007). Effect of fermentation on the chemical composition of mango (Mangifera indica) peels. African Journal of Biotechnology, 6 (6): 1979-1981.

Olajide, R. (2012). Growth performance, carcass, haematology and serum metabolites of broilers as affected by contents of anti-nutritional factors in soaked wild cocoyam (Colocasia esculenta (l.) schott) corm-based diets. Asian J. of Anim. Sci., 6: 23-32.

Onifade, A.A. and O.A. Abu, (1998). Productive response of rabbits to supplemental copper in a diet based on tropical feedstuffs. J. Appl. Anim. Res., 13: 129-135.

Onifade, A.A., A.A. Odunsi, G.M. Babatunde, B.R. Olorede and E. Muma (1999). Comparison of the supplemental effects of Saccharomyces cerevisiae and antibiotics in low protein and high fibre diets fed to broiler chickens. Archives of Animal Nutrition, 52(1): 29-39.
Piennar G.H., O.B. Einkamerer, H.J. Van Der Merwe, A Hugo, G.D. Scholtz and M.D. Fair (2012). The effect of an active live yeast product on the growth performance of finishing lambs. South Afr. J. Anim. Sci. Vol 42 (suppl. 1).

Reitman, S. and S. Frankel (1957). A calorimetric method for the determination of serumglutamic oxaloacetic and glutamic pyruvic transaminases. Amer. J. Clinc. Path., 28: 56.

Renard, C. (2001). Crop residues in mixed crop/livestock farming systems. CAB International in association with the association with the International Crops Research Institute for the Semi-Arid Tropics and the International Livestock Research Institute, pp. 25-36.

SAS Institute Inc., (2004). SAS/STAT 9.1 User's Guide: Statistics, SAS Institute Inc., Cary, N.C., USA.

Smith, D.L. (1982). Calcium oxalate and carbonate deposits in plant cells. In: The role of calcium in biology systems. L.J. Aughilori and A.M. Tuffet Anghilori (eds). CRS press, Boca Ration, FL., pp. 253- 261.

Stein, E.A. (1986). Textbook of Clinical Chemistry, NW Tietz, ed. W.B. Saunders, Philadelphia, pp. 879-886, 1818-1829.

Ukpabi, U.J. and J.I. Ejidoh (1989). Effect of deep oil frying on the oxalate content and the degree of itching of cocoyams (Xanthosoma and Colocassia spp). Technical paper presented at the 5th Annual Conference of the Agriculture Society of Nigeria, Federal University of Technology, Owerri, Nigeria, 3- 6 (September)

Wang, J.K. (1983). Taro, a review of Colocasia esculenta and its potential. University of Hawaii Press. pp. 300-312.

Warner, A.C.I. (1964). Production of volatile fatty acids in the rumen, methods of measurement. Nutr. Abst. and Rev., 34: 339.

Wikipedia, the free encyclopedia. http://en.wikipedia. org/wiki/Taro.

Williams, P.E.V. (1988). The action of yeast culture in the rumen. Feed Compounder 8 (9): 14.

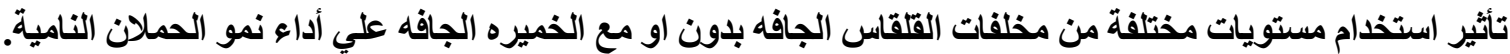

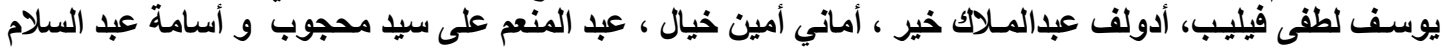

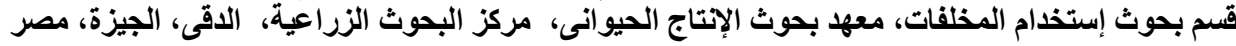

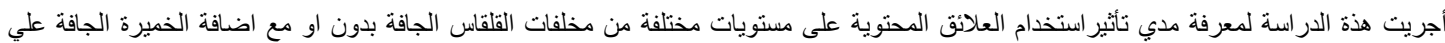

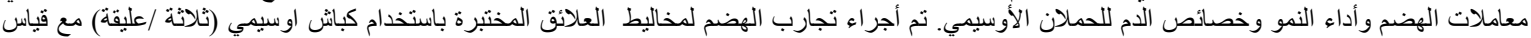

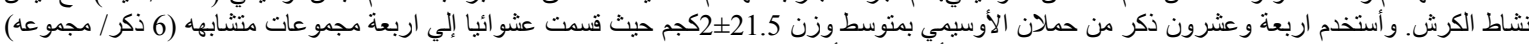

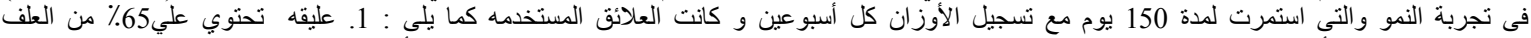

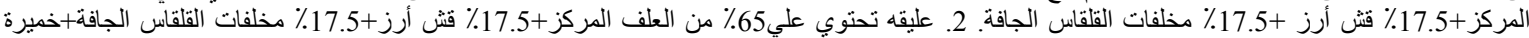

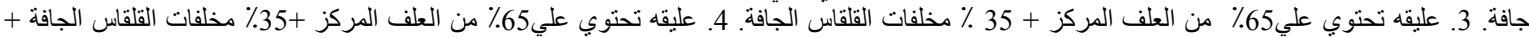

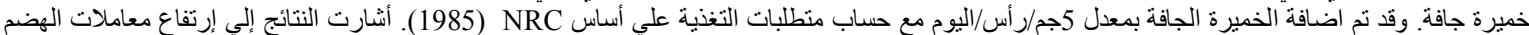

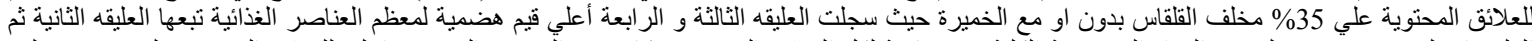

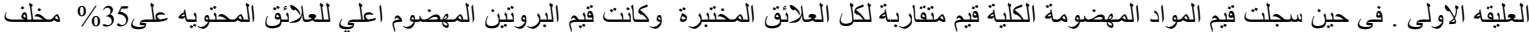

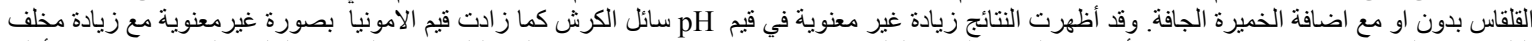

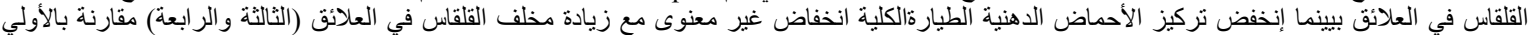

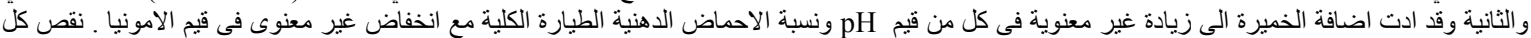

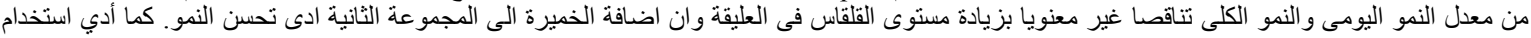

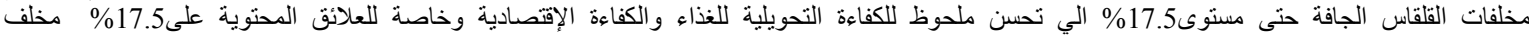

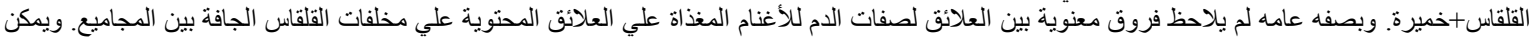

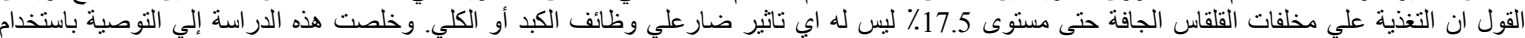
مخلفات القلقاس الجافة حتى مستوى 17.5 \% مع اضافة الخميرة الجافة في علائق الأغنام لما لذلك من تأثير على تحسن أداء نمو الحملان و ايضا الكفاءة الأقتصاديه. 